Environmental Conservation (2015) 42 (3): 227-236 (C) Foundation for Environmental Conservation 2015. The online version of this article is published within an Open Access environment subject to the conditions of the Creative Commons Attribution licence http://creativecommons.org/licenses/by/3.0/ doi:10.1017/S0376892915000077

\title{
Effort reduction and the large fish indicator: spatial trends reveal positive impacts of recent European fleet reduction schemes
}

\author{
GEORG H. ENGELHARD*, CHRISTOPHER P. LYNAM, BERNARDO GARCÍA-CARRERAS, \\ PAUL J. DOLDER AND STEVEN MACKINSON \\ Centre for Environment, Fisheries and Aquaculture Science (Cefas), Pakefield Road, Lomestoft NR33 0HT, UK
}

Date submitted: 17 September 2014; Date accepted: 30 December 2014; First published online 2 June 2015

\section{SUMMARY}

The large fish indicator (LFI), or 'proportion of fish greater than $40 \mathrm{~cm}$ length in bottom trawl surveys,' is a frequently debated indicator of Good Environmental Status in European regional seas. How does the LFI respond to changes in fishing pressure? This question is addressed here through analysis of fine-scale spatial trends in the LFI within the North Sea, compared between two periods of contrasting fisheries management: 1983-1999 and 2000-2012, respectively, before and after the onset of the European Union's fleet reduction scheme. Over the entire period, the LFI has decreased in large parts of the North Sea. However, most of the decline was from 1983-1999; since 2000 the LFI has improved in much of the North Sea, especially in UK waters. Comparison with international effort data shows that those western areas where the LFI has improved correspond with regions where otter trawl effort has decreased since 2000 (and previously was highest in the 1990s), and also with decreases in beam trawl effort. This study provides strong support that recent European effort reduction schemes are now beginning to result in an improved ecosystem state as indicated by the regional-scale improvement in the LFI.

Keymords: fishing effort, fleet reduction scheme, Good Environmental Status (GES), indicator, large fish indicator (LFI), Marine Strategy Framework Directive (MSFD), trawling impacts

\section{INTRODUCTION}

In marine ecosystems, large fish play an important trophic role at or near the top of the food chain, but are also of principal economic value to commercial fisheries, which often target the larger species or individuals (Jennings et al. 2001). Populations of large fish species tend to fluctuate less and in a more predictable manner than those of small species, and large species often yield higher prices per weight of catch (Pinnegar

*Correspondence: Georg H. Engelhard Tel: +44 1502527747 Fax: +441502513865 e-mail georg.engelhard@cefas.co.uk

Supplementary material can be found online at http://dx.doi.org/10.1017/S0376892915000077 et al. 2006); charismatic large fish have also significant cultural value, for example as they are primarily sought after by recreational fisheries (Jennings et al. 2001). Yet, it is also well known that large species are typically most vulnerable to the impacts of fishing, leading to reduced or truncated size distributions in both populations of species and whole fish communities (Jennings \& Kaiser 1998; Blanchard et al. 2014). This is why the status of large fishes in marine communities is increasingly recognized as an important indicator of ecosystem health.

The Marine Strategy Framework Directive (MSFD) tasks European Union (EU) member states to take the necessary measures to achieve or maintain Good Environmental Status (GES) in European seas by the year 2020 (EC [European Commission] 2008). Good Environmental Status should be determined on the basis of eleven qualitative descriptors, including biodiversity (descriptor 1) and food webs (descriptor 4). The Commission Decision of 1 September 2010 (EC 2010) clearly states that an indicator addressing the proportion of selected species at the top of food webs is required to monitor the structure of food webs for descriptor 4: namely the large fish indicator (LFI; Greenstreet et al. 2011; Shephard et al. 2011b). The Biodiversity Committee for the OSPAR Convention for the Protection of the Marine Environment of the North-East Atlantic has identified the LFI as a core indicator for biodiversity (descriptor 1) and has suggested that, with the inclusion of pelagic species, the indicator can be useful also for food webs (descriptor 4).

The MSFD (EC 2008) also states that adaptive management on the basis of the ecosystem approach with the aim of attaining good environmental status should be employed through a programme of measures, including input controls on human activities (such as fleet capacity measures or fishing effort limitation), output controls on perturbation of ecosystem components (for example change in state), and controls on the spatial and temporal distribution of human activities. An improved knowledge of the spatio-temporal response of the LFI to anthropogenic pressure is required to determine the optimal management of human activities to effect change in the environmental status.

The North Sea has been exploited for centuries by the surrounding countries and the state of its environment has been altered greatly by human activities (Garstang 1900; Jennings \& Kaiser 1998). Fisheries developed, expanded, and changed throughout the 20th century, with great increases in 
international effort from the 1960s through 1990s, coinciding with the introduction of intensive mechanized beam trawling, increasingly powerful vessel engines, fish-finding techniques such as sonar, and a wide range of other improvements in fishing technology (Engelhard 2008; Rijnsdorp et al. 2008). In the late 1990s, realizing that the pressure from fisheries had grown to unacceptable levels, the EU began a fleet reduction scheme in which decommissioning of vessels was paramount (Villasante 2010). Although it has been argued that the overall fishing power of the EU fleet did not change greatly as a result, the distribution of fishing activities changed, with larger vessels fishing in deeper waters gaining prominence (Villasante 2010). Since 2000, a reduction in total allowable catches (TACs) for most North Sea stocks and restrictions on days at sea have further contributed to reduced fishing activity levels (Greenstreet et al. 2009).

Greenstreet et al. (2011) showed that over this historic period, the LFI for the North Sea fish community declined from an average value of 0.3 in the early 1920 s to a historic minimum of 0.05 in 2001 , later recovering to 0.22 by 2008. They also showed that the decline in the LFI was correlated with the average fishing mortality on a range of commercially exploited demersal stocks in the North Sea in the preceding 12-20 years (cod Gadus morhua, haddock Melanogrammus aeglefinus, saithe Pollachius virens, whiting Merlangius merlangus, plaice Pleuronectes platessa, sole Solea solea, and Norway pout Trisopterus esmarkii). The authors speculated that the lagged relationship was not necessarily linear, but declines in the LFI may have resulted from a prolonged period of fishing above a given management reference point in the 1980s and 1990s (Greenstreet et al. 2011). The study justified a target LFI value of 0.3 , in line with the value adopted as indicator of GES (EC 2010). This raises the question: how does society manage human activities effectively in order to achieve this objective?

To help reveal the detail of whether and how the LFI responds to changes in fishing pressure, we investigated the spatial patterns of change across two periods, 1983-1999 and 2000-2012, characterized by contrasting fishing effort regimes, namely, before and after the onset of EU fleet reduction schemes. In both periods, we analyse if changes in the LFI can be related to the spatial distribution of trawling effort, which is known to be unevenly distributed and considerably higher in some than in other parts of the North Sea (Rijnsdorp et al. 1998; Greenstreet et al. 1999; Jennings et al. 1999). By demonstrating direct linkages between changes in the LFI and human activities in particular locations, we show how targeted adaptive management can be used successfully to manage actively toward GES. Specifically, we test the following hypotheses:

(1) Spatial patterns of change in the LFI were very different between 1983-1999 and 2000-2012, respectively, before and after the onset of the EU fleet reduction scheme;

(2) Spatial patterns of change in the LFI are associated with the spatial distribution of international trawling effort;
(3) Local reductions (or increases) in international trawling effort will be reflected in local improvements (or decreases) in the LFI.

\section{METHODS}

\section{Survey data and indicator calculation}

This paper uses the revised definition of the LFI (Greenstreet et al. 2011), namely the proportion by weight of fish over $40 \mathrm{~cm}$ in length in the North Sea demersal fish community, as sampled by International Bottom Trawl Surveys (IBTS) during quarter 1 (for a full description of the survey methods, see ICES [International Council for the Exploration of the Sea] 2012). IBTS data were downloaded from the ICES Database of Trawl Surveys (DATRAS, http://datras.ices.dk/Home/ Default.aspx). Data for the years 1983-2010 were downloaded on 14 October 2011 in the raw 'exchange data' format. This dataset was updated with 2011 data on 15 March 2012 and with 2012 data on 13 December 2012. The calculation of LFI values from these data involved numerous processing steps, as detailed by Fung et al. (2012). To determine yearly LFI values, the equation is as follows:

$$
L F I_{y}=\frac{\sum_{i} \sum_{j: L_{j}>40 c m} \sum_{k} \sum_{m} \rho_{i j k m y}}{\sum_{i} \sum_{j} \sum_{k} \sum_{m} \rho_{i j k m y}},
$$

where the numerator is the sum of biomass densities $\rho$ of all individuals with length $L>40 \mathrm{~cm}$ in year $y$, for each taxonomic group $i$, and length class $j$, for all valid hauls $k$, made by vessels $m$. The biomass density is equal to the biomass caught divided by the swept area, as in Fung et al. (2012). The denominator is simply the sum of the biomass densities of all fish individuals without application of the $40 \mathrm{~cm}$ length threshold. Whereas in Fung et al. (2012), Equation 1 was computed for the whole North Sea to obtain a single, North Sea-wide LFI value by year, here we determined yearly LFI scores by ICES rectangle, by computing Equation 1 for each rectangle separately.

Length-weight parameters to convert numbers of individuals to biomass estimates were taken from those reported by Fung et al. (2012). Following computation of the LFI scores by rectangle, the time-series of the LFI index for the entire North Sea was correlated with the values reported by Fung et al. (2012) as a validation of the coding exercise.

For each time-series of LFI by rectangle, a nonparametric rank-based trend analysis was conducted based on a correlation between the LFI values and an index of time corresponding to the temporal period over which observations were made. The statistic calculated in this way, Kendall's tau, has the notable benefit that the relationship between variables (year and LFI) may be any smoothly varying function (such as a curve) as expected for temporal changes in such an indicator. We interpret the estimates of tau for each rectangle in terms of the probability that a monotonic temporal trend exists in the LFI time-series for that rectangle. Tau scores range from -1 to +1 , namely a $100 \%$ probability of a decreasing or increasing trend, respectively. 
All analyses were made in $\mathrm{R}$ version 2.15.2 ( $\mathrm{R}$ Development Core Team 2012).

\section{Compilation of international effort data}

Although international landings data for the North Sea have been compiled by ICES since 1903 (for example see Kerby et al. 2012), no comparable long-term data on international fishing effort exist, let alone at the spatial detail of ICES rectangles. This is because traditionally countries have been required to provide information on fish landings, but no such legal requirements on effort data existed until the introduction of effort management regulations following the reform of the Common Fisheries Policy in 2002. Here we have compiled data on the spatial distribution of international trawling effort in the North Sea, for two periods: 1990-1995 (from Jennings et al. 1999) and 2003-2012 (from STECF [Scientific, Technical and Economic Committee for Fisheries] 2013). We acknowledge that, unfortunately, these periods could not be matched perfectly with the time-slots over which change in the LFI was calculated (1983-1999 and 2000-2013) but attribute this to the notorious difficulties in compiling international effort data, and note that this is the first time that a picture of the distribution of international trawling effort in the North Sea has been presented for two distinct time-periods preceding and following the onset of the $\mathrm{EU}$ fleet reduction scheme.

Trawling effort data for 1990-1995 were kindly provided by Simon Jennings (personal communication 2014). These represented the aggregate number of hours fishing by ICES rectangle for Danish, Dutch, English, German, Norwegian, Scottish and Welsh vessels, separated between beam trawlers (defined as any trawlers which towed nets supported by a rigid beam) and otter trawlers (defined as any vessels which towed bottom-fishing nets held open by trawl doors; Jennings et al. 1999). These data were not available for the countries separately, as originally agreed by the contributors to Jennings et al.'s (1999) study, as this would have required extensive collaboration with national administrations. The effort data, moreover, did not include Belgium and France, which had comparatively minor fishing interests in the North Sea (combined, these countries caught $6 \%$ of the total demersal landings in 1990-1995). For details on the data collection protocols by country, and the minimum sizes of vessels included, see Jennings et al. (1999).

EU effort data for the period 2003-2012 were sourced from the data appendix to the report by the Expert Working Group on Evaluation of Fishing Effort Regimes in European Waters Part 2, reviewed by the Scientific, Technical and Economic Committee for Fisheries (STECF 2013). The STECF dataset is publicly available at http://stecf.jrc.ec.europa.eu/data-reports, and amalgamated from submissions by EU member states in response to the current Data Collection Framework (DCF, previously the Data Collection Regulation; STECF 2013). The data consist of effort (number of hours fishing) per country, métier, vessel length category, and ICES rectangle. The STECF data were subset geographically to ICES sub-area IV (North Sea) to match spatially with the 1990-1995 effort data (Jennings et al. 1999). Activity is defined by the EU member state the métier relates to (namely gear used and mesh size range), and length category (STECF 2013). These were aggregated to create a beam trawl gear type (subcategories BEAM, BTI, BT2), and an otter trawl gear type (subcategories TRI, TR2, TR3, OTTER). All other gear types were removed for this analysis.

For the purpose of our study, it was important that the effort data (1) provided an appropriate description of the spatial distribution of trawling in the North Sea, and (2) would be comparable between the two time-periods 19901995 and 2003-2012. Unfortunately, this was hampered by three points. Firstly, although the STECF data account for a large proportion of the overall fishing activities in the North Sea, they do not include the Norwegian fleets, which are primarily active in the north-eastern and eastern North Sea (Greenstreet et al. 2007); by contrast the (aggregated) international effort data for 1990-1995 (Jennings et al. 1999) did include Norway, in that period responsible for a moderate (8\% in 1990) proportion of the total demersal landings from the North Sea (Kerby et al. 2012). Secondly, the way that fishing hours were reported to STECF differed between countries; whereas Denmark, the Netherlands, Germany, Belgium and France provided data on fishing hours, the UK (England and Scotland) provided data on 'days at sea multiplied by 24' (STECF 2013). However, fishing vessels only spend a proportion of the days at sea fishing, so that days at sea multiplied by 24 would give an overestimate of English and Scottish fishing hours compared to other European fleets, distorting the spatial distribution map and comparison between the 1990s and 2000s. Thus, English and Scottish trawl fishing hours data for 2003-2012 were estimated from days at sea using correction factors (see Supplementary material for details of estimation method; also see Greenstreet et al. 2007). Thirdly, for Belgium and France, effort data were available through STECF for 2003-2012 but not for 19901995; to facilitate the temporal comparison between the two decades, we excluded these two countries from the analysis, as their combined effort is only responsible for a fairly small fraction of the total demersal landings from the North Sea ( $c$. 6\% in 2009; Kerby et al. 2012).

\section{RESULTS}

\section{The LFI: spatial distribution and patterns of change}

The spatial distribution of the LFI within the North Sea has changed considerably over the period 1983-2012 (Fig. 1). Initially in the 1980s, high values of LFI $(>0.3)$ were distributed over many ICES rectangles throughout the entire area (Fig. 1a). By contrast, LFI values $>0.3$ have since then become rather limited to the northern- and easternmost fringes and along the Thames and Humber estuaries of the south-west (Fig. 1b,c). Around the turn of the millennium, 
Figure 1 Spatial distribution of the large fish indicator (LFI) for the North Sea fish fauna, shown separately for three-year time-windows at the beginning, middle, and end of the study period 1983-2012. Light to dark shading indicates the value of the LFI by ICES rectangle, averaged over each 3-year period (see legend).

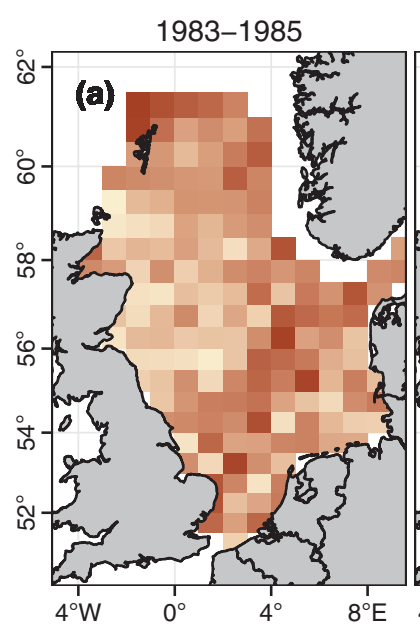

the LFI was particularly low in the western North Sea (Fig. 1b).

If considered over the entire study period 1983-2012, then LFI has generally decreased, especially in the central North Sea (Fig. 2a). This was indicated by mostly negative Kendall rank correlations (red symbols) of LFI with time in the majority of rectangles, many of these statistically significant $(p<0.05$; marked by crosses), and very few positive correlations (green symbols). However, patterns of change were very different between the periods 1983-1999 and 2000-2012. Most of the decreases in the LFI took place during the first part of the time-series (Fig. 2b), in the western and north-western parts of the North Sea. By contrast, over the period 2000-2012, the LFI has improved or remained stable over most parts of the North Sea, especially in those central-western and north-western rectangles where LFI had previously declined most (Fig. $2 c$, note green symbols marked by crosses, indicating significant positive trends over time).

\section{International trawling effort: distribution in the $1990 \mathrm{~s}$ and 2000s}

The distribution of international trawling effort in the North Sea was such that some areas were trawled much more
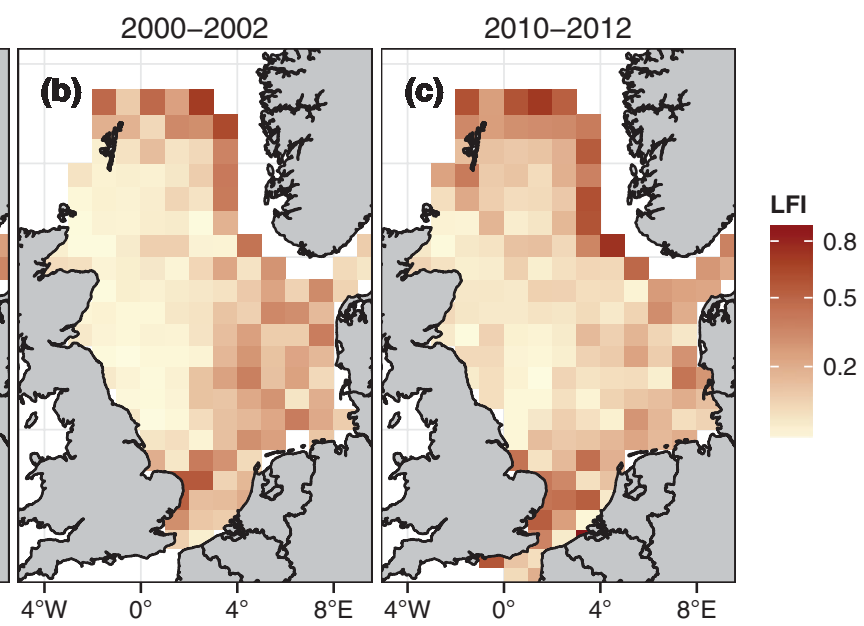

intensively than other areas during both periods where we were able to compile a reasonably complete picture of international effort: 1990-1995 (from Jennings et al. 1999) and 2003-2012 (from STECF 2013), and this was the case for both beam and otter trawlers (Fig. 3). It should be noted that our data, unfortunately, do not include Belgian and French effort, and for the 2000s exclude Norwegian effort.

During the 1990s, international beam trawl effort was especially high and widespread in the central and southern North Sea, with moderate beam trawling off eastern Scotland (Fig. 3a). In the 2000s, beam trawl effort reduced considerably, became increasingly concentrated in the southeast, and is currently very limited near Scotland (Fig. 3b). International otter trawl effort, in both periods, was widely distributed throughout the entire North Sea. However, while in the 1990s otter trawling was especially concentrated in the central-western and north-western parts (Fig. 3c), there appears to have been no appreciable change in total effort and a redistribution towards the east (Fig. $3 d$ ). Otter trawling in the 2000s was more concentrated in the deeper northeastern parts of the North Sea, and has also increased in some shallower parts in the German Bight. We acknowledge that the 2000s data exclude Norwegian effort, but inclusion would have

Figure 2 Patterns of change in the large fish indicator (LFI) for the North Sea fish fauna, $(a)$ over the entire period 1983-2012, (b) for the first part of the time-series (1983-1999), and (c) for the second part of the time-series (2000-2012). The maps show, for each ICES rectangle, whether the LFI has either increased (green) or decreased (red) over the time-span considered (using Kendall's rank correlation); crosses indicate statistically significant correlations $(p<0.05)$.
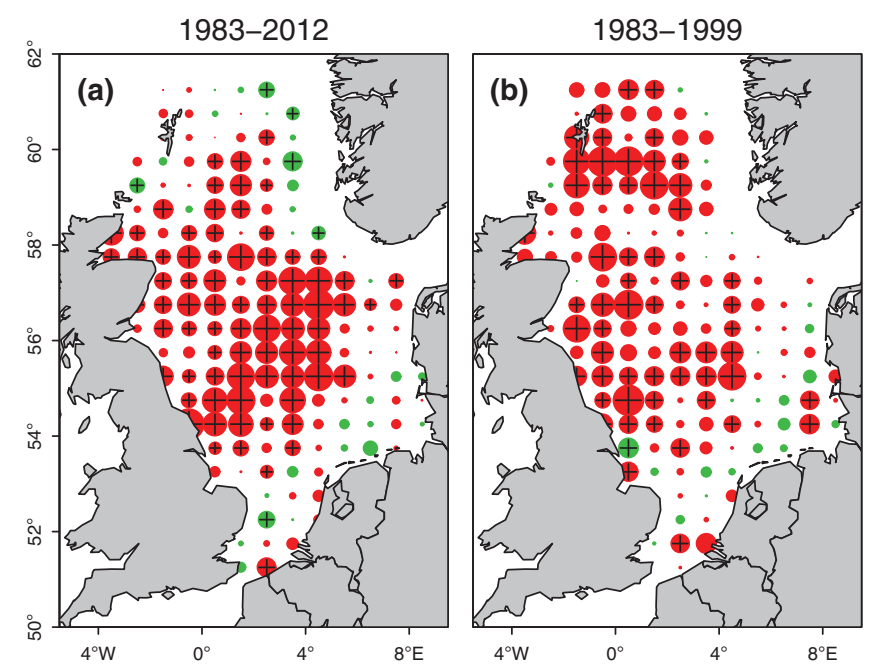
Figure 3 Spatial distribution of international fishing effort in the North Sea by beam trawlers (top) and demersal otter trawlers (bottom), averaged by year over the periods 1990-1995 (left) and 2003-2012 (right). Light to dark shading indicates the number of hours fishing in each rectangle (on a $\sqrt{ }$-scale). Data for the 1990s from Jennings et al. (1999); 2000s data from STECF (2013). Note some discrepancy in the countries included for each time period: 1990s data include Denmark, England, Germany, Netherlands, Norway, Scotland and Wales; 2000s data include Denmark, England, Germany, Netherlands, Scotland and Wales.

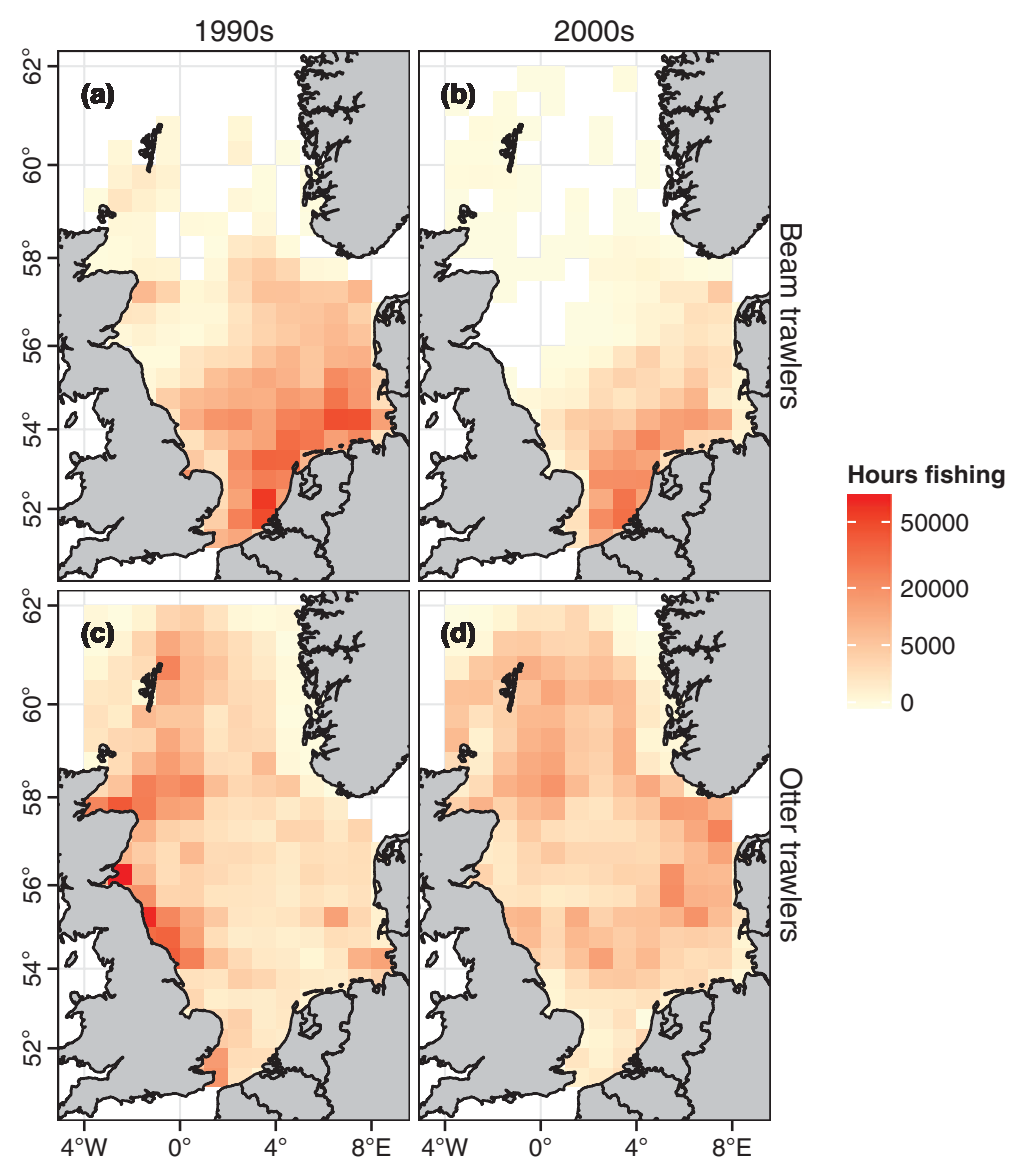

aggravated the signal of an eastward shift in effort, because Norwegian effort is more concentrated in the east.

The redistribution of international trawling effort becomes even clearer when the change in otter or beam trawl effort between the 1990s and 2000s is visualized for each ICES rectangle separately (Fig. 4). Clearly, levels of otter trawling have declined in many western rectangles near the coasts of England and Scotland (Fig. 4a, blue-shaded cells), but increased in the east (red-shaded cells). Beam trawling has increased moderately in the south but clearly declined in the northern and central North Sea (Fig. 4b); although 7 rectangles in the north did show high proportional increase (shaded red), the total beam trawl levels in these are still low (as these rectangles were unfished by beam trawlers in the 1990s).

\section{International trawling effort: links with change in the LFI}

The spatial distribution of otter trawling in the 1990s was significantly negatively associated with patterns of change in the LFI from 1983-1999 (Table 1). In 56 rectangles where the LFI declined, annual otter trawl effort was significantly higher than in 99 rectangles where the LFI did not decline (median 3108 versus $2102 \mathrm{~h}$ fishing $\mathrm{yr}^{-1}$ rectangle $^{-1}$; Mann-Whitney, $p$ $=0.044$ ). Beam trawl effort in the 1990s was not significantly different between rectangles where the LFI declined, or did not decline (Table 1; median 452 versus $2694 \mathrm{~h}$ fishing $\mathrm{yr}^{-1}$ rectangle $^{-1}$; Mann-Whitney, $\left.p=0.096\right)$.

During the 2000s, 18 rectangles where the LFI improved significantly were similar in levels of otter trawling to 137 rectangles where the LFI did not show a significant increase (Table 2; median 3722 versus $3647 \mathrm{~h}$ fishing $\mathrm{yr}^{-1}$ rectangle $^{-1}$; Mann-Whitney, $p=0.95$ ). Beam trawl effort, however, was significantly less in the former than in the latter (median 0 versus $96 \mathrm{~h}$ fishing $\mathrm{yr}^{-1}$ rectangle $^{-1}$; Mann-Whitney, $p=$ $0.0003)$.

Moreover, there was significant evidence that reductions in trawling effort between the 1990s and 2000s (see Fig. 4) were significantly associated with improvements in the LFI during 2000-2012 (Table 2). This was the case for both otter trawling (median effort reduced by $-23.2 \%$ in rectangles where LFI improved, and median effort increased by $+18.7 \%$ in rectangles where LFI did not increase; Mann-Whitney, $p=$ 0.0047 ) and beam trawling (median effort reduced by $-99.9 \%$ and $-79.1 \%$ in rectangles where LFI improved and did not improve, respectively; Mann-Whitney, $p=0.00011$ ).

This was confirmed when change in LFI during 2000-2012 was compared between rectangles where otter trawling either decreased or increased from the 1990 s to 2000s (Table 3): in the former $(n=65)$, Kendall's tau values (proxy for LFI change) were significantly higher than in the latter $(n=90$; $t$ test, $p=0.022$ ). Likewise, in 80 rectangles where beam 
Figure 4 Patterns of change in international trawling effort in the North Sea between the 1990s and 2000s, shown separately for otter trawlers $(l e f t)$ and beam trawlers (right). Blue- and red-shading indicate reduced and more intensified effort, respectively. For each rectangle, change in effort is quantified here as annual mean effort over 1990-1995 ( $\left.\mathrm{E}_{1990 \mathrm{~s}}\right)$ subtracted from the mean over 2003-2012 ( $\left.\mathrm{E}_{2000 \mathrm{~s}}\right)$, standardized by sum of mean effort in both periods. Data sources as in Figure 3; note that 2000s data exclude Norwegian effort.

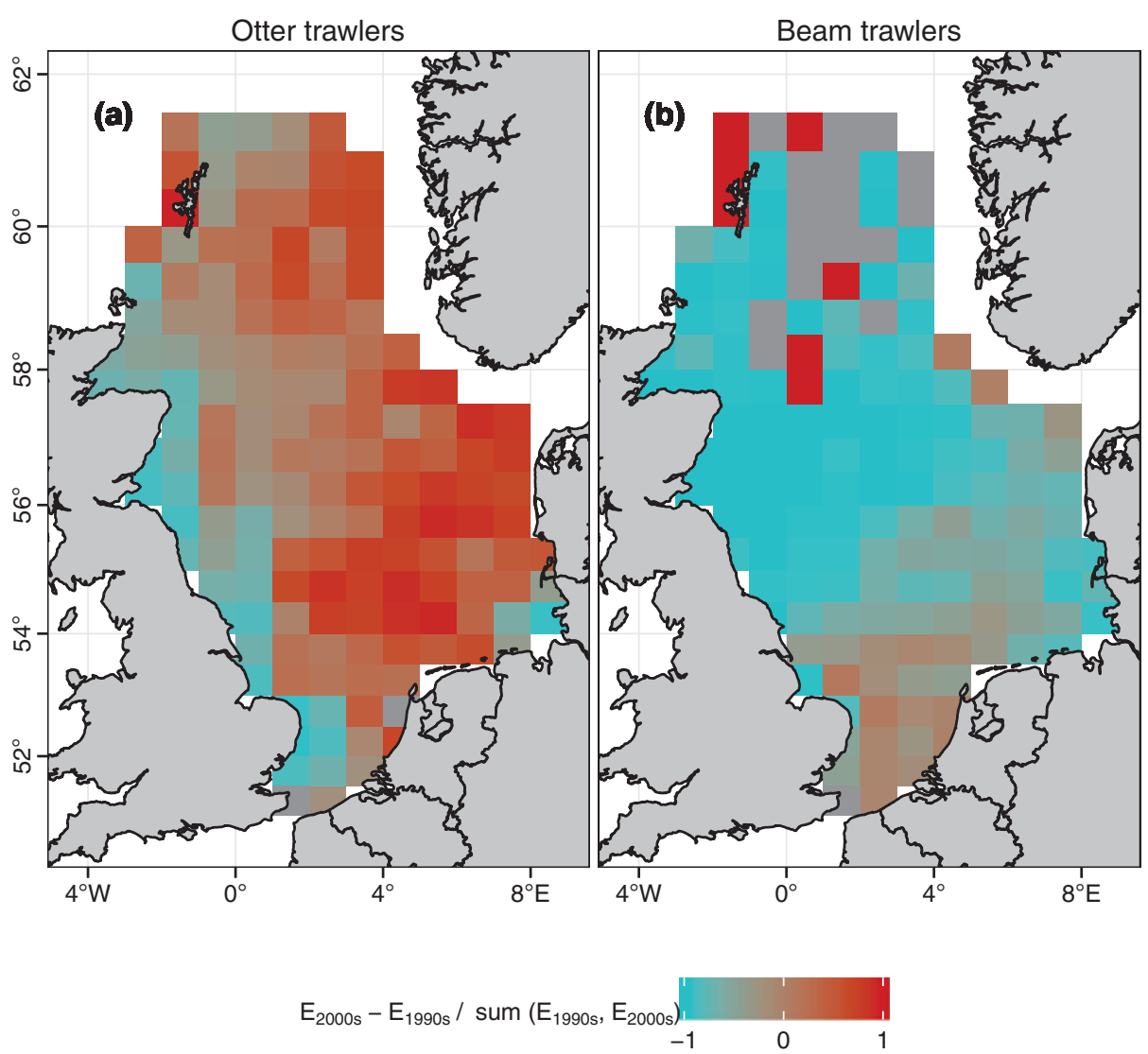

Table 1 Comparison of trawling effort (1990s) between ICES rectangles where the large fish indicator (LFI) declined significantly and ICES rectangles where the LFI did not show a significant decline, over the period 1983-1999. * Significant difference $p<$ 0.05 .

\begin{tabular}{|c|c|c|c|c|}
\hline & \multicolumn{2}{|c|}{ Median effort ( $25 \%, 75 \%$ quantiles) in: } & \multicolumn{2}{|c|}{ Mann-Whitne\} } \\
\hline & $\begin{array}{l}\text { Rectangles mhere LFI declined significantly } \\
\qquad n=56\end{array}$ & $\begin{array}{l}\text { Rectangles where LFI did not decline } \\
n=99\end{array}$ & $W$ & $p$ \\
\hline Otter trawl effort & $\begin{array}{c}3108 \\
(1525,7833)\end{array}$ & $\begin{array}{c}2071 \\
(1161,4425)\end{array}$ & 3313 & $0.044^{*}$ \\
\hline Beam trawl effort & $\begin{array}{c}452 \\
(82,7151)\end{array}$ & $\begin{array}{c}2694 \\
(69,13472)\end{array}$ & 2723 & 0.096 \\
\hline
\end{tabular}

Table 2 Trawling effort (2000s) and reductions in trawling effort (from 1990s to 2000s), compared between ICES rectangles where the large fish indicator (LFI) improved significantly, and ICES rectangles where the LFI did not significantly improve, over the period $2000-2012$. * Significant difference $p<0.05$.

\begin{tabular}{|c|c|c|c|c|}
\hline & \multicolumn{2}{|c|}{ Median (change in) effort (25\%, $75 \%$ quantiles) in: } & \multicolumn{2}{|c|}{ Mann-Whitney } \\
\hline & $\begin{array}{l}\text { Rectangles where LFI improved significantly } \\
\qquad n=18\end{array}$ & $\begin{array}{l}\text { Rectangles where LFI did not improve } \\
n=137\end{array}$ & $W$ & $p$ \\
\hline Otter trawl effort & $\begin{array}{c}3722 \\
(1717,7295)\end{array}$ & $\begin{array}{c}3647 \\
(1602,7744)\end{array}$ & 1230 & 0.95 \\
\hline Beam trawl effort & $\begin{array}{c}0 \\
(0,6)\end{array}$ & $\begin{array}{c}96 \\
(1,2101)\end{array}$ & 597 & $0.0003^{*}$ \\
\hline Change in otter trawl effort & $\begin{array}{c}-23.2 \% \\
(-44.5 \%,+7.8 \%)\end{array}$ & $\begin{array}{c}+18.1 \% \\
(-22.9 \%,+59.8 \%)\end{array}$ & 733 & $0.0053^{*}$ \\
\hline Change in beam trawl effort & $\begin{array}{c}-99.9 \% \\
(-100 \%,-96.7 \%)\end{array}$ & $\begin{array}{c}-79.1 \% \\
(-96.9 \%,-45.8 \%)\end{array}$ & 363 & $0.00011^{*}$ \\
\hline
\end{tabular}


Table 3 Kendall's tau values (proxy for large fish indicator change during 2000-2012) compared between ICES rectangles differing in the extent to which trawling was reduced (or increased) from the $1990 \mathrm{~s}$ to $2000 \mathrm{~s}$. * Significant difference $p<0.05$.

\begin{tabular}{|c|c|c|c|c|c|}
\hline & \multirow[t]{2}{*}{$n$} & \multirow[t]{2}{*}{ Kendall's tau values (mean $\pm S E$ ) } & \multicolumn{3}{|c|}{ Student's t test } \\
\hline & & & $t$ & $d f$ & $p$ \\
\hline Rectangles where otter trawl effort decreased & 65 & $0.179 \pm 0.033$ & \multirow{2}{*}{-2.32} & \multirow{2}{*}{139} & \multirow{2}{*}{$0.022^{*}$} \\
\hline Rectangles where otter trawl effort increased & 90 & $0.077 \pm 0.029$ & & & \\
\hline $\begin{array}{l}\text { Rectangles where beam trawl effort decreased } \\
\text { substantially (by }>75 \% \text { ) }\end{array}$ & 80 & $0.159 \pm 0.033$ & \multirow{2}{*}{-2.60} & \multirow{2}{*}{135} & \multirow{2}{*}{$0.010^{*}$} \\
\hline $\begin{array}{l}\text { Rectangles where beam trawl effort decreased less } \\
\text { (by }<75 \% \text { ) or increased }\end{array}$ & 59 & $0.039 \pm 0.032$ & & & \\
\hline
\end{tabular}

trawling was reduced by over $75 \%$, Kendall's tau values were significantly higher than in 59 rectangles where beam trawling was reduced by less than $75 \%$, or not reduced $(t$ test, $p=$ $0.010)$. Thus, rectangles in the western North Sea where otter trawling was reduced most, tended to be those which saw significant improvements in the LFI; and those rectangles (mainly in the south or east) where otter or beam trawling increased, tended to be those that saw a lack of improvement (compare Fig. $2 c$ with Fig. 4).

\section{DISCUSSION}

This study provides strong evidence that the large fish indicator for the North Sea is directly responsive to trawling pressure. Firstly, we have shown that the LFI is unevenly distributed over the North Sea, with greater concentrations of large fish in some areas (the northern, north-eastern, and south-westernmost fringes) than in others, although during the 1980s the LFI was distributed much more evenly than now. Secondly, the spatial distribution of trawling is also very heterogeneous (see also Rijnsdorp et al. 1998; Jennings et al. 1999) and has changed recently, with areas trawled more intensively in the 1990 s coinciding with greater reductions in the LFI from 1983-1999; areas where trawling has been reduced since then, have shown better recoveries in the LFI from 2000-2012 than other areas. Thirdly, although the LFI has significantly improved since 2000 in especially the western North Sea, it is not yet at levels comparable to the 1980s (in line with Greenstreet et al. 2011; Fung et al. 2012, 2013; and see Shephard et al. 2013 on lack of recovery in the Celtic Sea LFI).

The uneven distribution of the LFI is unsurprising and partly reflects the distribution patterns of the two predominant species in the 'large fish component' of the LFI: cod and saithe (Greenstreet et al. 2011). Saithe have a generally northerly, deeper-water distribution (Homrum et al. 2013), and cod have shown major range shifts within the North Sea since the $1970 \mathrm{~s}$, to a distribution that is currently further north, east, and deeper than it has been throughout the 20th century (Engelhard et al. 2014; see also Dulvy et al. 2008). The shift in cod distribution has been attributed to both climate change and fishing pressure (Engelhard et al. 2014), and the latter is in line with the significant relationships between LFI and trawling distribution reported here. A third, important species within the 'large fish component,' haddock, has also shown a northward shift, in particular the southern range boundary within the North Sea has moved north (Skinner 2009).

In the south-western North Sea, areas off the Thames Estuary and the Wash stood out by locally high values of the LFI. These areas are not only visited in winter by spawning cod (Righton et al. 2007), but are also spawning and nursery grounds for several elasmobranch species, notably thornback ray Raja clavata, spotted ray Raja montagui and tope shark Galeorhinus galeus (Ellis et al. 2005; Hunter et al. 2006). These are considered vulnerable to fishing pressure and of conservation concern. The importance of the region for these larger fish species adds additional evidence to the designation of two special areas of conservation (SAC) in the outer Thames Estuary (Margate and Long Sands; Essex Estuaries) and the North Norfolk Coast SACs, and supports the currently proposed designation of the Wash Approach recommended Marine Conservation Zone (rMCZ; www.jncc.defra.gov.uk/page-4549).

Improvement in the LFI since the late 1990s, at the North Sea-average scale, has previously been suggested to relate to reductions in fishing mortality $F$ (Greenstreet et al. 2011). However, the North Sea-averaged LFI was linked to community-averaged $\mathrm{F}$, namely the mean of annual $\mathrm{F}$ estimates over a range of demersal fish stocks exploited in the North Sea (cod, haddock, saithe, whiting, plaice, sole, and Norway pout), with a 12-18 year time-lag (Greenstreet et al. 2011; and see Modica et al. 2014 for an analogous study on the LFI in the Bay of Biscay). Community-averaged F had previously also been linked to fish size spectra in the North Sea (Daan et al. 2005). This supported the relationship between pressure (community-averaged F) and state (stock biomasses; size spectra; LFI). For the Celtic Sea, fine-scale spatial correlations between fishing effort and the LFI had been reported, but no link with temporal change in the LFI (Shephard et al. 2011a). The present study complements this work by providing direct statistical evidence for the relationship between the activity (trawling effort; which can be managed) that induces the pressure $(\mathrm{F})$, and responsiveness of 
the LFI (the variable to be monitored), being the full chain:

$$
\begin{aligned}
\text { Activity (effort) } & \rightarrow \text { Pressure }(\mathrm{F}) \rightarrow \text { State (stocks) } \\
& \rightarrow \text { Indicator }(\mathrm{LFI}) .
\end{aligned}
$$

Areas otter-trawled most intensively during the 1990s (central-western, north-western North Sea) were those that saw the greatest reductions in the LFI over 1983-1999, resulting in an (albeit temporary) 'depletion' of the LFI in this region towards the turn of the millennium. Indeed, otter trawlers (with $>100-\mathrm{mm}$ mesh) directly target those roundfish species (cod, saithe, and haddock) that predominate the numerator of the LFI (the large fish component). The area was also intensively fished by Nephrops trawlers (with $80-\mathrm{mm}$ mesh) which, while targeting Nephrops, can have considerable bycatches of cod and whiting Merlangius merlangus (Catchpole et al. 2005; Ungfors et al. 2013), although only the largest of whiting will contribute to the 'large fish component'. Hence, the catch and bycatch composition of the otter trawl fleets supports the notion that high otter trawling effort in the west during the 1990s (and probably during the preceding decade too; Houghton \& Flatman 1981) resulted in a regional depletion of large fish.

Although the LFI in a statistical rectangle was associated with the trend in fishing effort in that rectangle, it will likely also be affected by the development in fishing effort in a larger area. This is because many of the fish species that make up the assemblage at the time of the survey (first quarter), upon which the LFI is based, perform seasonal migrations between spawning and feeding areas (Righton et al. 2007; Homrum et al. 2013), and will be exposed to fishing pressure in other areas during part of the year (Hunter et al. 2006). This will introduce an element of uncertainty in the correlation between local fishing effort and the LFI. However, in spite of this, significant and meaningful relationships between effort and the LFI at rectangle level were demonstrated.

This is the first study, to our knowledge, where the spatial distribution of international otter and beam trawl effort in the North Sea was described and contrasted between two distinct time periods, the 1990s and 2000s. Although the overall EU fleet size has been reduced (Villasante 2010), the reduction in trawling pressure has not been even throughout the North Sea. While otter trawling was especially reduced in the west off the English and Scottish coasts but increased in the north-east and south-east, beam trawling decreased in northern and western parts but stayed about constant in the south. The redistribution of otter trawling might be a response to the distribution shift and local depletions of large gadoids (including cod: Dulvy et al. 2008; Engelhard et al. 2014), thus fleets likely redistributed their effort in order to follow their target species. The local increase of otter trawling in the German Bight (south-eastern North Sea) might be explained by a recent shift in plaice fisheries, from (fuel-intensive) beam trawling to (less fuel-demanding) otter trawling (STECF
2013), even though beam trawlers remain the predominant fleet targeting flatfish in the North Sea.

To an extent, the reduction in effective trawling pressure might be less than suggested here based on fishing hours as proxy for effort, owing to 'technological creep' (increasing catchability: Engelhard 2008; Eigaard et al. 2014). For example, twin trawls have been used more widely, which have substantially wider widths than conventional otter trawls (Eigaard et al. 2014). Conversely, most beam trawlers have reduced their towing speeds to compensate for rising fuel prices, hence their effective fishing effort would have been reduced even further than reported here based on fishing hours (Abernethy et al. 2010). We expect that technological creep, although potentially complicating interpretation of temporal trends in effective effort, would not have appreciably influenced our results, based on analysis of spatial patterns of change in effort (Figs 3 and 4).

In spite of recent improvements in the LFI, it is worth noting that current levels are not yet comparable to those that characterized the 1980s, when high LFI was distributed almost throughout the North Sea. Indeed, community modelbased analyses have suggested that recovery rate may decline after an initial bounce owing to trophic interactions, such that full recovery may take many decades (Fung et al. 2013; Shephard et al. 2013). Moreover, the 1980s marked the later stage of the 'gadoid outburst', two decades from the mid-1960s to mid-1980s when productivity of gadoid stocks in the North Sea was unusually high, and not only cod, but also saithe, haddock and whiting produced some of the largest year-classes on record (Daan 1978; Jones \& Hislop 1978). The precise causes behind the gadoid outburst are still not fully understood, but it is believed that the relatively cold environmental conditions of the 1960s to mid1980s favoured the productivity of gadoids and several other large-bodied, cold-water (boreal) fish species (Daan 1978); in addition, overfishing and subsequent collapse of herring Clupea harengus in the 1960s-1970s might have temporarily released large gadoids from predation on eggs and larvae (Daan 1978; Cushing 1980). Since the 1980s, the North Sea has warmed significantly (Holt $e t a l$. 2012). This has led to dramatic increases in the stock sizes of many warm-water (Lusitanian) fish species characterized by small body sizes, and unfavourable conditions for a range of boreal species with on average larger body sizes (Beare et al. 2004; Engelhard et al. 2011; ter Hofstede \& Rijnsdorp 2011). Within stocks, warmer temperatures appear to have led to reductions in growth rates and asymptotic body sizes (Baudron et al. 2014). The North Sea fish community has also shifted from a predominance of demersal species to a greater abundance of (typically smaller-sized) pelagic species (Kenny et al. 2009; Engelhard et al. 2011). Therefore, in spite of reductions in trawling pressure, a return of the LFI to the levels of the 1980s may be compromised by prevailing conditions: the current warmer climatic regime favours Lusitanian above boreal species, and small pelagic above demersal fishes (Kenny 
et al. 2009; Engelhard et al. 2011; ter Hofstede \& Rijnsdorp 2011).

The significant increases in the LFI in those regions where trawling effort was reduced since the turn of the millennium demonstrate the benefits of management action and successful implementation by the fishing industry. This provides strong evidence that reductions in fishing pressure can pay off in terms of improvements in a key indicator of GES, within the reasonably short time-span of $c .10$ years. This is a promising signal that EU effort reduction schemes aimed at improving profitability of fisheries and moving towards GES, are beginning to pay off.

\section{ACKNOWLEDGEMENTS}

This study would not have been achievable without our international STECF colleagues who compile and qualityassure data on fishing effort for the 2000s during annual meetings, or without Simon Jennings who provided the 1990s effort data. Large Fish Indicator data were included in the European Marine Ecosystem Observatory (EMECO) Datatool (www.emecodata.net) and will become available in future. The study benefited from feedback from John Pinnegar, Axel Rossberg, Tracy Maxwell, Eva Garnacho, and three anonymous referees. This work was supported by the Department for Environment, Food and Rural Affairs of the UK (Defra project MF1228 'Physics to Fisheries'), with additional support from the European Union (Framework 7 project 308392 'Devotes') and from Defra project ME5427 'Meeting the Assessment Needs of the MSFD'.

\section{Supplementary material}

To view supplementary material for this article, please visit http://dx.doi.org/10.1017/S0376892915000077.

\section{References}

Abernethy, K.E., Trebilcock, P., Kebede, B., Allison, E.H. \& Dulvy, N.K. (2010) Fuelling the decline in UK fishing communities? ICES Journal of Marine Science 67: 1076-1085.

Baudron, A.R., Needle, C.L., Rijnsdorp, A.D. \& Marshall, C.T. (2014) Warming temperatures and smaller body sizes: synchronous changes in growth of North Sea fishes. Global Change Biology 20: 1023-1031.

Beare, D.J., Burns, F., Greig, A., Jones, E.G., Peach, K., Kienzle, M., McKenzie, E., Reid, D.G. (2004) Long-term increases in prevalence of North Sea fishes having southern biogeographic affinities. Marine Ecology Progress Series 284: 269-278.

Blanchard, J.L., Andersen, K.H., Scott, F., Hintzen, N.T., Piet, G. \& Jennings, S. (2014) Evaluating targets and trade-offs among fisheries and conservation objectives using a multispecies size spectrum model. Fournal of Applied Ecology 51: 612-622.

Catchpole, T.L., Frid, C.L.J. \& Gray, T.S. (2005) Discards in North Sea fisheries: causes, consequences and solutions. Marine Policy 29: 421-430.
Cushing, D.H. (1980) The decline of the herring stocks and the gadoid outburst. Fournal du Conseil International pour l'Exploration de la Mer 39: 70-81.

Daan, N. (1978) Changes in cod stocks and cod fisheries in the North Sea. Rapports et Procès-Verbaux des Réunions du Conseil International pour l'Exploration de la Mer 172: 39-57.

Daan, N., Gislason, H., Pope, J.G. \& Rice, J.C. (2005) Changes in the North Sea fish community: evidence of indirect effects of fishing? ICES Journal of Marine Science 62: 177-18.

Dulvy, N.K., Rogers, S.I., Jennings, S., Stelzenmüller, V., Dye, S.R. \& Skjoldal, H.R. (2008) Climate change and deepening of the North Sea fish assemblage: a biotic indicator of warming seas. Fournal of Applied Ecology 45: 1029-1039.

EC (2008) Directive 2008/56/EC of the European Parliament and of the Council of 17 June 2008 establishing a framework for community action in the field of marine environment policy (Marine Strategy Framework Directive). Official fournal of the European Union L164: 19-40.

EC (2010) Commission Decision of 1 September 2010 on criteria and methodological standards on good environmental status of marine waters (2010/477/EU). Official Fournal of the European Union L232: 14-24.

Eigaard, O.R., Marchal, P., Gislason, H. \& Rijnsdorp, A.D. (2014) Technological development and fisheries management. Reviems in Fisheries Science E Aquaculture 22: 156-174.

Ellis, J.R., Cruz-Martínez, A., Rackham, B.D. \& Rogers, S.I. (2005) The distribution of chondrichthyan fishes around the British Isles and implications for conservation. Fournal of Northmest Atlantic Fisheries Science 35: 1-19.

Engelhard, G.H. (2008) One hundred and twenty years of change in fishing power of English North Sea trawlers. In: Advances in Fisheries Science 50 Years on from Beverton and Holt, ed. A. Payne, J. Cotter \& T. Potter, pp. 1-25. Oxford, UK: Blackwell Publishing. Engelhard, G.H., Ellis, J.R., Payne, M.R., ter Hofstede, R. \& Pinnegar, J.K. (2011) Ecotypes as a concept for exploring responses to climate change in fish assemblages. ICES fournal of Marine Science 68: 580-591.

Engelhard, G.H., Righton, D.A. \& Pinnegar, J.K. (2014) Climate change and fishing: a century of shifting distribution in North Sea cod. Global Change Biology 20: 2473-2483.

Fung, T., Farnsworth, K.D., Reid, D.G. \& Rossberg, A.G. (2012) Recent data suggest no further recovery in North Sea Large Fish Indicator. ICES Journal of Marine Science 69: 235-239.

Fung, T., Farnsworth, K.D., Shephard, S., Reid, D.G. \& Rossberg, A.G. (2013) Why the size structure of marine communities can require decades to recover from fishing. Marine Ecology Progress Series 484: 155-171.

Garstang, W. (1900) The impoverishment of the sea. Fournal of the Marine Biological Association of the UK 6: 1-69.

Greenstreet, S.P.R., Holland, G.J., Fraser, T.W.K. \& Allen, V.J. (2009) Modelling demersal fishing effort based on landings and days absence from port, to generate more useful indicators of 'activity'. ICES Fournal of Marine Science 66: 886-901.

Greenstreet, S., Robinson, L., Piet, G., Craeymeersch, J., Callaway, R., Reiss, H., Ehrich, S., Kröncke, I., Fraser, H., Lancaster, J., Jorgensen, L. \& Goffin, A. (2007) The ecological disturbance caused by fishing in the North Sea. Fisheries Research Services Collaborative Report 04/07, Fisheries Research Services, Marine Laboratory, Aberdeen, Scotland, UK.

Greenstreet, S.P.R., Rogers, S.I., Rice, J.C., Piet, G.J., Guirey, E.J., Fraser, H.M. \& Fryer, R.J. (2011) Development of the EcoQO for 
the North Sea fish community. ICES Journal of Marine Science 68: 1-11.

Greenstreet, S.P.R., Spence, F.B., Shanks, A.M. \& McMillan, J.A. (1999) Fishing effects in northeast Atlantic shelf seas: patterns in fishing effort, diversity and community structure. II. Trends in fishing effort in the North Sea by UK registered vessels landing in Scotland. Fisheries Research 40: 107-124.

Holt, J., Hughes, S., Hopkins, S., Wakelin, S.J., Holliday, N.P., Dye, S., González-Pola, C., Hjøllo, S.S., Mork, K.A., Nolan, G., Proctor, R., Read, J., Shammon, T., Sherwin, T., Smyth, T., Tattersall, G., Ward, B. \& Wiltshire, K.H. (2012) Multidecadal variability and trends in the temperature of the northwest European continental shelf: a model-data synthesis. Progress in Oceanography 106: 96-117.

Homrum, E. í, Hansen, B., Jónsson, S.P., Michalsen, K., Burgos, J., Righton, D., Steingrund, P., Jakobsen, T., Mouritsen, R., Hátún, H., Armannsson, H. \& Joensen, J.S. (2013) Migration of saithe (Pollachius virens) in the Northeast Atlantic. ICES Fournal of Marine Science 70: 782-792.

Houghton, R.G. \& Flatman, S. (1981) The exploitation pattern, density dependent catchability and growth of cod in the west-central North Sea. Fournal du Conseil International pour l'Exploration de la Mer 39: 271-287.

Hunter, E., Berry, F., Buckley, A.A., Stewart, C. \& Metcalfe, J.D. (2006) Seasonal migration of thornback rays and implications for closure management. Fournal of Applied Ecology 43: 710720 .

ICES (2012) Manual for the International Bottom Traml Surveys. Series of ICES Survey Protocols, SISP 1-IBTS VIII, Copenhagen, Denmark: $68 \mathrm{pp}$

Jennings, S., Alvsvåg, J., Cotter, A.J.R., Ehrich, S., Greenstreet, S.P.R., Jarre Teichmann, A., Mergardt, N., Rijnsdorp, A.D. \& Smedstad, O. (1999) Fishing effects in northeast Atlantic shelf seas: patterns in fishing effort, diversity and community structure. III. International trawling effort in the North Sea: an analysis of spatial and temporal trends. Fisheries Research 40: $125-134$.

Jennings, S. \& Kaiser, M. (1998) The effects of fishing on marine ecosystems. Advances in Marine Biology 34: 201-352.

Jennings, S., Kaiser, M.J. \& Reynolds, J.D. (2001) Marine Fisheries Ecology. Oxford, UK: Blackwell Science.

Jones, R. \& Hislop, J.R.G. (1978) Changes in North Sea haddock and whiting. Rapports et Procès-Verbaux des Réunions du Conseil International pour l'Exploration de la Mer 172: 58-71.

Kenny, A.J., Skjoldal, H.R., Engelhard, G.H., Kershaw, P.J. \& Reid, J.B. (2009) An integrated approach for assessing the relative significance of human pressures and environmental forcing on the status of Large Marine Ecosystems. Progress in Oceanography 81: $132-148$.

Kerby, T.K., Cheung, W.W.L. \& Engelhard, G.H. (2012) The United Kingdom's role in North Sea demersal fisheries: a hundred year perspective. Reviems in Fish Biology and Fisheries 22: 621-634.
Modica, L., Velasco, F., Preciado, I., Soto, M. \& Greenstreet, S.P.R. (2014) Development of the large fish indicator and associated target for a Northeast Atlantic fish community. ICES Journal of Marine Science 71: 2403-2415.

Pinnegar, J.K., Hutton, T.P. \& Piacenti, V. (2006) What relative seafood prices can tell us about the status of stocks. Fish and Fisheries 7: 219-226.

R Core Team (2012) R: A language and environment for statistical computing. R Foundation for Statistical Computing, Vienna, Austria. ISBN 3-900051-07-0 [www document]. URL http://www.R-project.org/

Righton, D., Quayle, V.A., Hetherington, S. \& Burt, G. (2007) Movements and distribution of $\operatorname{cod}($ Gadus morhua $)$ in the southern North Sea and English Channel: results from conventional and electronic tagging experiments. Fournal of the Marine Biological Association of the UK 87: 599-613.

Rijnsdorp, A.D., Buys, A.M., Storbeck, F. \& Visser, E.G. (1998) Micro-scale distribution of beam trawl effort in the southern North Sea between 1993 and 1996 in relation to the trawling frequency of the sea bed and the impact on benthic organisms. ICES fournal of Marine Science 55: 403-419.

Rijnsdorp, A.D., Poos, J.J., Quirijns, F.J., HilleRisLambers, R., de Wilde, J.W. \& Den Heijer, W.M. (2008) The arms race between fishers. Fournal of Sea Research 60: 126-138.

Shephard, S., Fung, T., Rossberg, A.G, Reid, D.G., Greenstreet, S.P.R. \& Warnes, S. (2013) Modelling recovery of Celtic Sea demersal fish community size-structure. Fisheries Research 140: 91-95.

Shephard, S., Gerritsen, H.D., Kaiser, M.J., Truszkowska, H.S. \& Reid, D.G. (2011a) Fishing and environment drive spatial heterogeneity in Celtic Sea fish community size structure. ICES Fournal of Marine Science 68: 2106-2113.

Shephard, S., Reid, D.G. \& Greenstreet, S.P.R. (2011b) Interpreting the large fish indicator for the Celtic Sea. ICES Journal of Marine Science 68: 1963-1972.

Skinner, J.A. (2009) The changing distribution of haddock Melanogrammus aeglefinus in the North Sea: effects of fishing effort and environmental variation over the last century. MSc Thesis, University of East Anglia, Norwich, UK.

STECF (2013) Evaluation of Fishing Effort Regimes in European Waters. Part 2 (STECF-13-21). Publications Office of the European Union, Luxembourg, EUR 26327 EN, JRC86088, doi: $10.2788 / 95715$.

ter Hofstede, R. \& Rijnsdorp, A.D. (2011) Comparing demersal fish assemblages between periods of contrasting climate and fishing pressure. ICES fournal of Marine Science 68: 11891198.

Ungfors, A., Bell, E., Johnson, M.L., Cowing, D., Dobson, N.C., Bublitz, R. \& Sandell, J. (2013) Nephrops fisheries in European waters. Advances in Marine Biology 64: 247-314.

Villasante, S. (2010) Global assessment of the European fishing fleet: an update. Marine Policy 34: 663-670. 